\title{
Familial hyperaldosteronism type III
}

INSERM

\section{Source}

INSERM. (1999). Orphanet: an online rare disease and orphan drug data base. Familial hyperaldosteronism type III. ORPHA:251274

Familial hyperaldosteronism type III (FH-III) is a rare heritable form of primary aldosteronism (PA) that is characterized by early-onset severe hypertension, non glucocorticoid-remediable hyperaldosteronism, overproduction of 18-oxocortisol and 18hydroxycortisol, and profound hypokalemia. 